from $S$. demissum. However, in addition to the $R$ gene resistance, 'field resistance' was also known which is at present effective against all races. The approach now being made is to combine $R$ genes with the 'field resistance', which is inherited polygenically, so that varieties could be produced with a high level of resistance to some, and 'field resistance' to all, races.

The final discussion was opened by Prof. C. T. Ingold who, after surveying the various methods used for identifying physiological races of pathogenic fungi, turned to the more genetical aspects of problems. He considered that the importance of the parasexual cycle was not fully appreciated and in the future needed further investigation on a broad front.

This symposium drew together geneticists, virologists, pathologists and plant breeders who were involved in improving the productivity of crop plants.
It is to be hoped that this will be the first of a series of such joint meetings in which scientists of different disciplines can consider together topics of common interest. These discussions were, however, particu. larly opportune as the rapid advances made in micro. bial genetics, the information collected as a result of expanded breeding programmes and the experience gained in handling resistant varieties in the past decade, need careful integration if the undoubted benefits of disease resistance are to be fully exploited. Although few fundamentally new ideas emerged from the papers it was clear that the complexities of incorporating stable forms of resistance in commercially acceptable varieties were fully realized. There was nevertheless a feeling that, at least for some crops, the future promised an improved standard of disease resistance based largely upon mechanisms controlled by minor gene systems.

R. C. F. Macer

\title{
THE DEVELOPMENT OF SCIENCE IN SOUTH-EAST ASIA
}

A REGIONAL meeting, to discuss problems of organizing scientific research in South-East Asian countries, was held at Bandung, Indonesia, during December 9-12, 1959. It was organized jointly by the Unesco South-East Asia Science Co-operation Office and the Indonesian Council of Sciences, and was attended by senior representatives of the national research organizations or other appropriate bodies of the following countries: Australia, Hong Kong, India, Indonesia, Japan, Malaya, Philippines, Thailand, Republic of Vietnam, and New Zealand. The meeting was inaugurated with an opening address by the Minister of Education, Instruction and Culture of Indonesia, Prof. Prijono, in the National Planning Board building in Bandung, which had been the scens of the historic Afro-Asian Conference in 1955. Prof. Prijono emphasized that the development of science and technology has not always been accompanied by moral progress, and appealed to the delegates to apply their learning for universal development, based on the common needs of man. The president of the Council of Sciences of Indonesia, Prof. Sarwono Prawirohardjo, was elected ehairman of the meeting.

The business sessions of the meeting were held in the impressive headquarters of the National Science Foundation of Indonesia. From the outset of the discussions, stress was laid on informality. It was believed that a frank exchange of views would be more beneficial than formal debates on a number of fixed points, and this indeed proved to be the case. The stages of scientific development of the countries attending the meeting varied considerably-some had long-established government scientific research organizations, whereas others had only recently set up such bodies. After a survey of the main features of government research organization in each country, delegates discussed some of the major organizational problems which they faced. One of these was to determine the optimum balance between fundamental and applied research which they should undertake. It was recognized that developing countries have many urgent problems requiring immediate practical solution, and that it is usually easier to persuade governments to provide funds for research which has a definite practical objective. The traditional role of the universities in research is also to undertake fundamental work. Nevertheless, the meeting felt most strongly that it is essential for the health of national research organizations that they should be free to undertake fundamental work as they think desirable, and to approach any applied problem as basically as is necessary.

Another problem was concerned with the proper responsibilities of a national research organization. These, of course, vary with the country concerned. In some countries of the region the national scientific organizations are operating bodies, maintaining their own laboratories and employing their own staff; in others they are co-ordinating bodies advising their governments on development of policy and distribution of funds. The meeting stressed that in either case it is essential that the national scientific organization should have the maximum possible degree of autonomy of operation and in administering the funds provided for it by its government.

The relative functions of universities and national research organizations were also discussed. It is essential that university research should be effective in training students in the practice and philosophy of research, and for this reason governments should be prepared to provide funds for university research without any conditions as to the projects on which they should be employed.

One particularly interesting discussion covered the conditions for attracting and holding good scientists in the service of national research organizations. This is a vital matter, particularly for countries with national organizations in the early stages of development. The meeting placed great weight on the need for providing as liberal employment conditions as possible. Scientists look for autonomy of the organization, and freedom from political interference and rigid departmental control; the provision of suitable salaries and other conditions of service such as adequate equipment and trained assistance ; freedom. of publication; liberal travel grants and study leave, ete. It was also agreed that it is most important that the management of scientific organizations should be in the hands of scientists.

As was inevitable at such a meeting, the provision of finance and resources for research eame in for 
considerable discussion. It was recognized that the main burden for this falls on governments, particularly in developing countries where the situation is made more difficult because there is little or no industry to provide additional funds. It was suggested that countries providing assistance for developing countries should be prepared to allocate a larger proportion of their aid funds for scientific research. It is essential, however, that a proper balance should be maintained between the provision of training opportunities in the shape of fellowships, etc., and the provision of equipment and facilities. Training is useless if the trainees do not have equipment and facilities available on their return to their home countries; on the other hand, it is useless to provide expensive and complicated equipment if skilled staff is not available to use it properly.

The encouragement of scientific research in developing countries through regional collaboration in such activities as conferences, symposia and training courses was a major topic of discussion. This led naturally to a discussion of the programme of the Unesco South-East Asia Science Co-operation Office, which is already fulfilling such an important role in the region. In relation to the needs, however, its resources are much too limited, and the meeting agreed that Unesco should be asked to make a greatly increased budgetary provision for its work in the area. The meeting agreed that the following activities, which are all urgently needed in the region, could appropriately be undertaken by Unesco: the provision of information on research programmes being undertaken in the region and on facilities for training and technical assistance; the encouragement of symposia on scientific subjects of special interest to
South-East Asia; the provision of training courses for technicians, and refresher courses for science teachers; the encouragement of more visits to the region by scientists. The meeting suggested that the Unesco South-East Asia Science Co-operation Office should consider the possibility of arranging a meeting of librarians and documentation experts of the area. and it recommended that the present and proposed programmes of the Office in the fields of science teacher training, marine science research and humic tropics research should be confirmed and strengthened.

The whole conference demonstrated clearly how effective international meetings on a limited scale can be in promoting understanding and friendship. I believe that the meeting will have valuable practical results in increasing active collaboration between countries of the region in seientific matters. Many of them have scientific problems in common, and it was clear from the discussions at Bandung that they face many similar organizational and administrative problems in building up and strengthening their scientific organizations. The Unesco South-East Asia Science Co-operation Office is to be congratulated in taking the initiative in arranging the meeting, and it is obvious from the discussions that it can play a much greater part in the scientific life of the region if it can be provided with greater support. Such increased activity would be welcomed by all countries represented at the meeting.

All the delegates to the meeting would agree that it was a most successful one, and they have carried away with them the happiest memories of the gracious hospitality of their Indonesian colleagues, and the exquisite beauty of the Java countryside.

GUY B. GRESFORD

\section{RECENT ADVANCES IN COCONUT RESEARCH IN INDIA}

$\mathrm{T}$ HE Agricultural College, Vellayani, Trivandrum, was the venue of the first conference of the coconut research workers in India organized by the Indian Central Coconut Committee, Ernakulam. India is the second largest producer of coconuts, a commodity occupying an important place in international commerce. With the advent of the Indian Central Coconut Committee in 1945 and with the establishment of two Central Coconut Research Stations and seven Regional Research Stations in the different coconut-growing States of the country, coconut researeh has in recent years gained considerable impetus and it was therefore quite opportune that research workers engaged from all over India should meet and discuss recent advances achieved in their field of work. The Conference was held during December 21-23, 1959, and was attended by more than seventy research workers, representatives of the Kerala Department of Agriculture and the Agricultural College, and some prominent coconut growers. Prof. L. S. S. Kumar, principal of the Agricultural College, presided. Some forty-five papers were presented and discussed at the conference.

Eleven papers covered the subjects falling under the purview of agronomy and general plant nutrition. In the first paper, by Mr. M. M. Krishna Marar and Dr. K. M. Pandalai (Kasaragod), the results of observations made in some long-term (40-year) experi- mental plots on the coconut were presented. The more important of the conclusions drawn were that (1) regular inter-cultivation and manuring are necessary to step up and maintain the yield at high level, and (2) regular inter-cultivation by itself is highly effective in increasing the yields even in the absence of manuring.

The same authors discussed in another paper the beneficial effects of nitrogen, phosphorus and potassium manuring on inducing flowering and bearing in adult non-bearing palms. Messrs. C. M. John and K. Jacob (Bangalore) reviewed the results of the extensive fertilizer demonstration scheme on coconuts carried out in growers' holdings on the west coast of India and established that manuring with the standard dose of $0.75 \mathrm{lb}$. nitrogen, $0.75 \mathrm{lb}$. phosphate and $1.5 \mathrm{lb}$. potassium together with 50-100 $\mathrm{lb}$. green leaves per tree per year resulted in an increase of 35 per cent in terms of nuts, or 44 per cent in terms of copra, providing a net profit of Rs. 88.00 per acre. Miss K. Vijayalakshmi (Kasaragod) dealt with the various factors regarding moisture in soils of coconut plantations and outlined the various steps to be taken to conserve it. Messrs. T. Kailas Rao and T. Srirama Rao (Ambajipet) showed that for the alluvial soils of the coconut areas of Andhra Pradesh, sunnhemp is the most suitable green manure crop. The practices that have to be tackled when 